\title{
Neotectonics induced by ice-sheet advances in NE Poland
}

\author{
WOJCIECH MORAWSKI
}

Polish Geological Institute, Rakowiecka 4, 00-975 Warsaw, Poland; e-mail: wojciech.morawski@pgi.waw.pl

\begin{abstract}
Differences in the geological structure of the hard-rock substratum of the Warmia and Mazury regions (NE Poland) resulted during the Pleistocene in different reactions on the load exerted by the land-ice masses. In the (western) Warmia province, vertical glacio-isostatic movements caused cyclic erosional events affecting the relatively thick sedimentary cover, which became more compacted. In contrast, the thinner sedimentary cover of the rigid crystalline basement favoured quiet sedimentation in the (eastern) Mazury province. The zone in between these two areas runs NNE-SSW for some $80 \mathrm{~km}$. It is several kilometres wide and is composed of landforms that owe their origin to the sedimentary infilling of crevasses. This intermediate zone formed an interlobe are between the two huge ice lobes that covered the Warmia and Mazury areas during the last ice age. The basement of the zone coincides with the crystalline craton slope, which is accompanied to the west by a parallel marginal trough.

Cyclic advances and retreats of the Pleistocene ice sheet induced neotectonic mobility. Glacio-isostatic processes resulted in the intermediate zone in block movements (uplift and subsidence) that affected the whole Cenozoic succession, creating mainly vertical discontinuity zones. Glacio-isostasy also induced vertical tectonic movements within the older deposits, reaching down to the crystalline basement. A tectonic graben thus developed. It is bounded by flexures accompanied on both sides by positive structures that may indicate transpressional movements with a strike-slip stress component.
\end{abstract}

Keywords: neotectonics, glacioisostasy, glaciotectonics, geophysical investigations, Pleistocene, NE Poland

\section{Introduction}

It was found during the preparation of the 1:50,000 Detailed Geological Map of Poland that differences exist between the Pleistocene of the Warmia and Mazury regions (NE Poland). On this basis, a (more western) Warmia and (more eastern) Mazury palaeogeographic province can be distinguished (Fig. 1).

In the western area, erosion dominated over glacial sedimentation throughout the Pleistocene, and numerous hiatuses occur, rep- resenting particularly interglacials. The baseQuaternary is irregular, with deep incisions into the glacitectonically thrusted Neogene deposits, locally even to the hard-rock substratum. The eastern region had more quiet sedimentation during the Pleistocene glacials and interglacials, resulting in laterally continuous sedimentary units. The base-Quaternary is commonly flat in this eastern area.

The Warmia and Mazury provinces most likely coincide with the extent of two lobes of the last (Vistulian) ice sheet that invaded the 


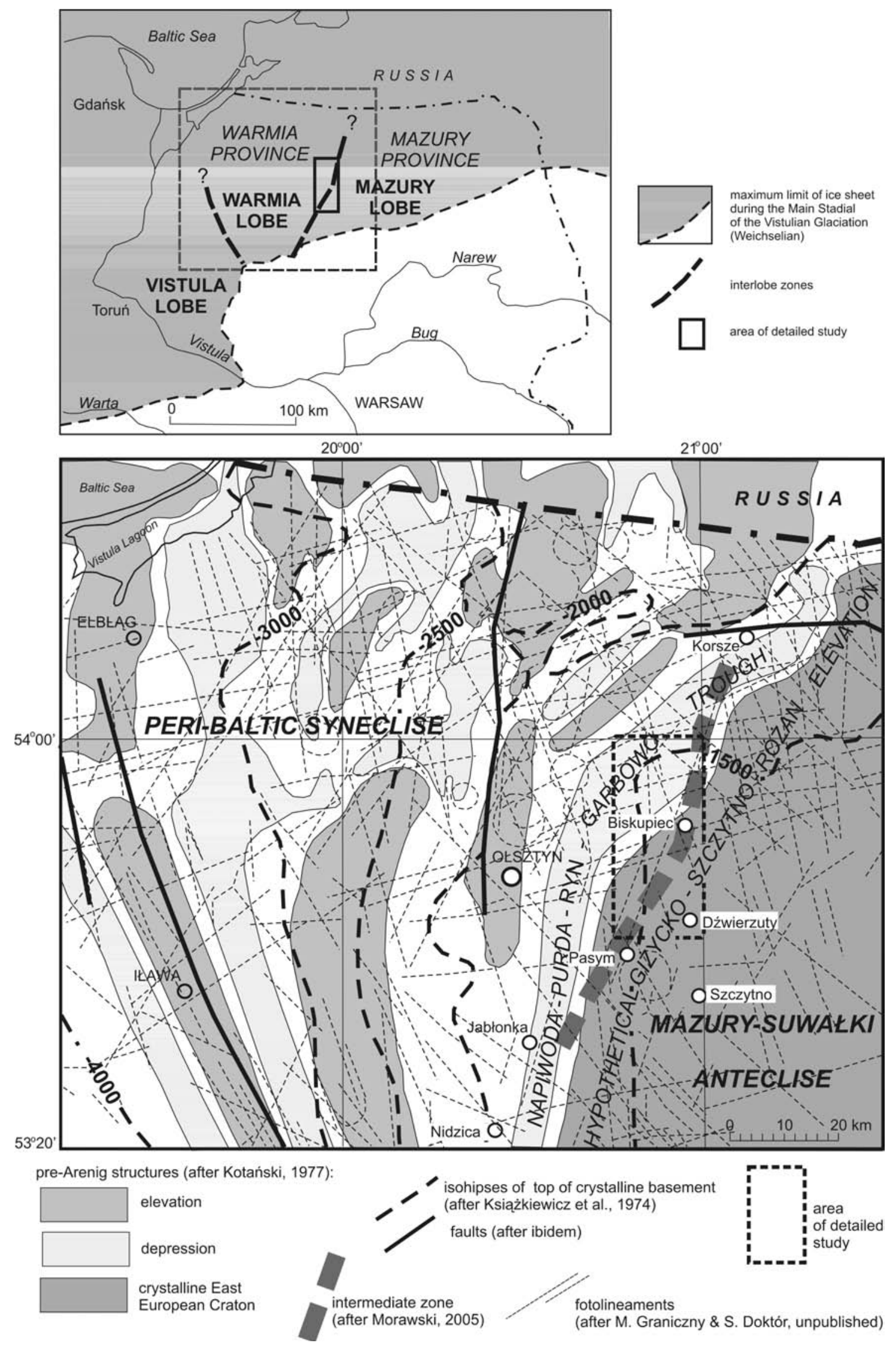

Fig. 1. Location of intermediate zone and tectonic structures of the basement. 


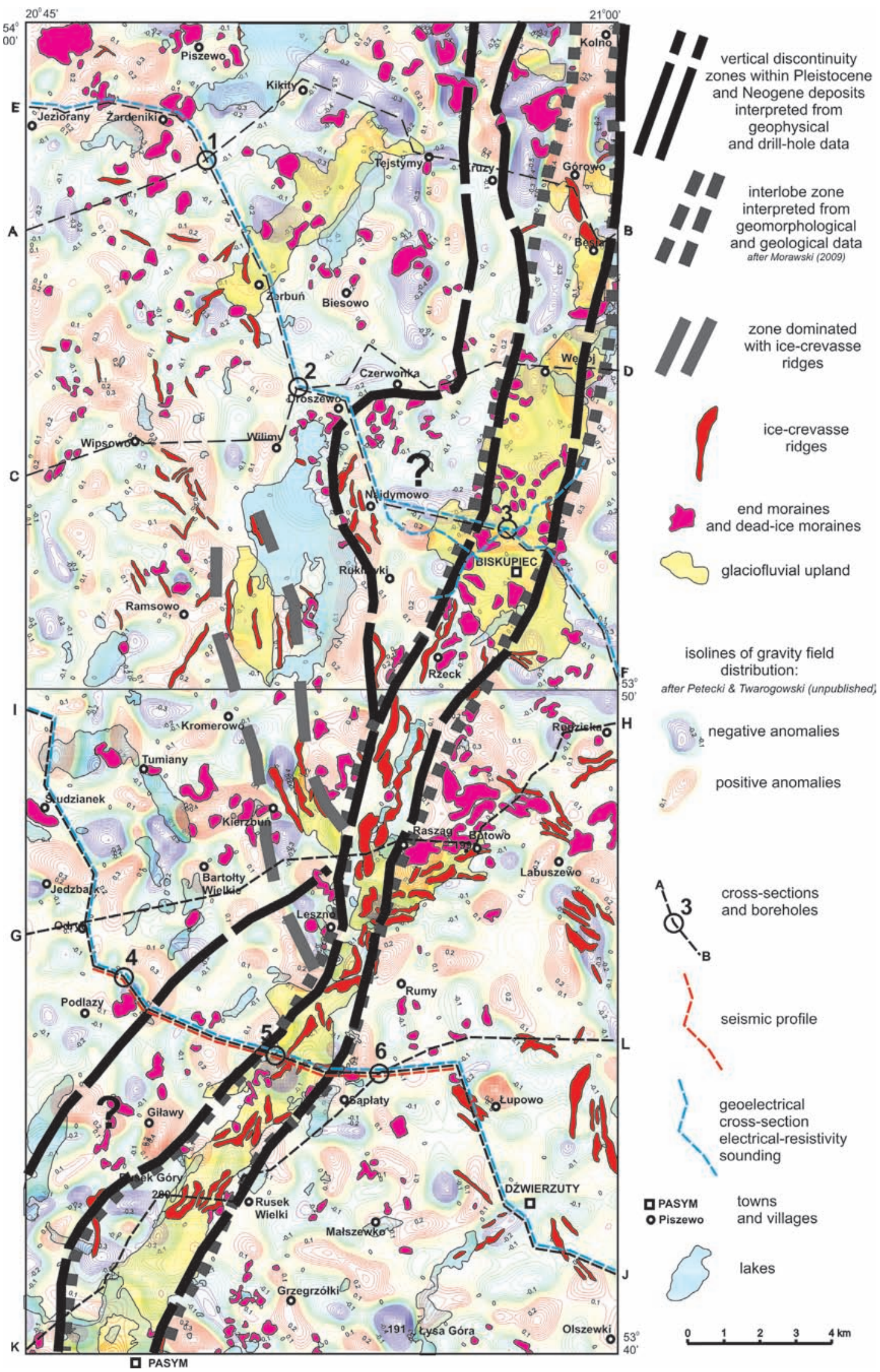

Fig. 2. Intermediate zone against the background of gravity anomalies map. 
region, viz. the Warmia and Mazury ice lobes (Fig. 1). The boundary of the two areas follows a NNE-SSW trending belt of some $80 \mathrm{~km}$ long (called the 'intermediate zone' in the following) of elongated depositional landforms. Its topography is best pronounced in the central sector, between Kolno, Biskupiec and Pasym, where detailed geological and geophysical investigations were carried out (Figs. 1, 2). This interlobe area is a few kilometres wide (Morawski, 2003, 2009d-this issue).

Structural analysis suggests that the intermediate zone between the provinces coincides with the southern segment of the marginal trough stretching along the western slope of the crystalline craton (Fig. 1). The trough separates two regional structural units: the Peribaltic Syneclise (to the West) and the Mazury-Suwałki Anteclise (to the East). The Peribaltic Syneclise is characterized by a deep-seated crystalline basement and a tectonically disturbed sedimentary cover of considerable thickness $(2-4 \mathrm{~km})$. On the Mazury-Suwałki Anteclise, the crystalline craton is covered by a much thinner sedimentary succession (1-1.5 km).

Differences in the prevailing processes in the two palaeogeographic provinces during the Pleistocene may have resulted from different reactions of the crystalline substratum to periodic loading and unloading resulting from successive advances and retreats of the Pleistocene ice sheets. It seems that the eastern region behaved in a stable way, whereas the crystalline basement of the western area was much more mobile. The much larger vertical glacio-isostatic movements in the western province influenced the glacial and postglacial processes. Downward movements induced by the ice-sheet load may have controlled the velocity and the changes in direction of the ice mass: both the thrusting and subsidence of blocks caused ice to pile up, and resulted in deep glaciotectonic deformation. It also triggered strong erosion at the base of the ice sheet.

These processes probably resulted in the development of the Warmia lobe (Morawski, 2009d-this issue). In turn, glacio-isostatic rebound, induced by retreating ice masses, could cause intense erosional processes, resulting in hiatuses representing particularly interglacials.
The crystalline-craton slope and the parallel marginal trough in particular formed mobile zones during the Pleistocene.

Thus, the question arises of what was the relationship between the orientation of structures in the hard-rock substratum and the elongation of the zone separating the Warmia and Mazury lobes of the last glaciation; and of what is the geological structure of the intermediate zone; and of what processes shaped this zone. The objective of the present contribution is to answer these questions. To elucidate these problems, field investigations were carried out in the central part of the interlobe zone along a section of $40 \mathrm{~km}$ long between Kolno in the North, through Biskupiec, to Pasym in the South (Fig. 2).

\section{Research methods}

Geological mapping, geomorphological and geophysical investigation, as well as borehole and laboratory analyses were carried out. They cover an area of about $600 \mathrm{~km}^{2}$ of the central part of the intermediate zone (Fig. 2). General data on the area could thus be obtained, with particular emphasis on its structural characteristics. The results of lithological, stratigraphical and sedimentological investigations of the Pleistocene and older Cenozoic deposits, based mainly on drilling data, are discussed elsewhere in this issue (Morawski, 2009d-this issue; Słodkowska, 2009-this issue).

Field mapping was performed at a scale of 1:25,000. The reconstruction of local and regional directions of the Warmia and Mazury ice lobes during the last glaciation was made by analysing the orientation of glacial landforms (morpholineaments) (Morawski, 2003, 2005b, 2009d-this issue).

Material from 300 boreholes was analysed and interpreted, including the complete cores from six wells: (1) Żardeniki (to a depth of 153 m), (2) Wilimy (268 m), (3) Biskupiec (248 m), (4) Klucznik (303 m), (5) Nerwik (141 m) and (6) Sąpłaty (300 m). Boreholes 1, 2 and 4 are located in the Warmia province, borehole 6 is in the Mazury province, whereas boreholes 3 and 5 were drilled in the centre of the interme- 
diate zone (Fig. 2). These six boreholes span the complete Pleistocene. Boreholes 2, 4 and 6 spanned also the almost complete Cenozoic. All six cores were sampled for analysis of their lithology and petrography. Palynological and microfaunal investigations of almost the complete Neogene and Palaeogene (including the Danian) were performed on samples from boreholes 4 and 6 (Słodkowska, 2009-this issue).
The deep geological structure of the intermediate zone was geophysically examined earlier (Z. Petecki \& J. Twarogowski, unpublished), so that local gravity-anomaly maps were already available for the area of detailed study (Fig. 2). Seismic and geoelectrical measurements, as well as boreholes were concentrated along cross-section I-J, running across the intermediate zone, thus encompassing the area between the Warmia and Mazury provinces (Fig. 3). A 12-km long

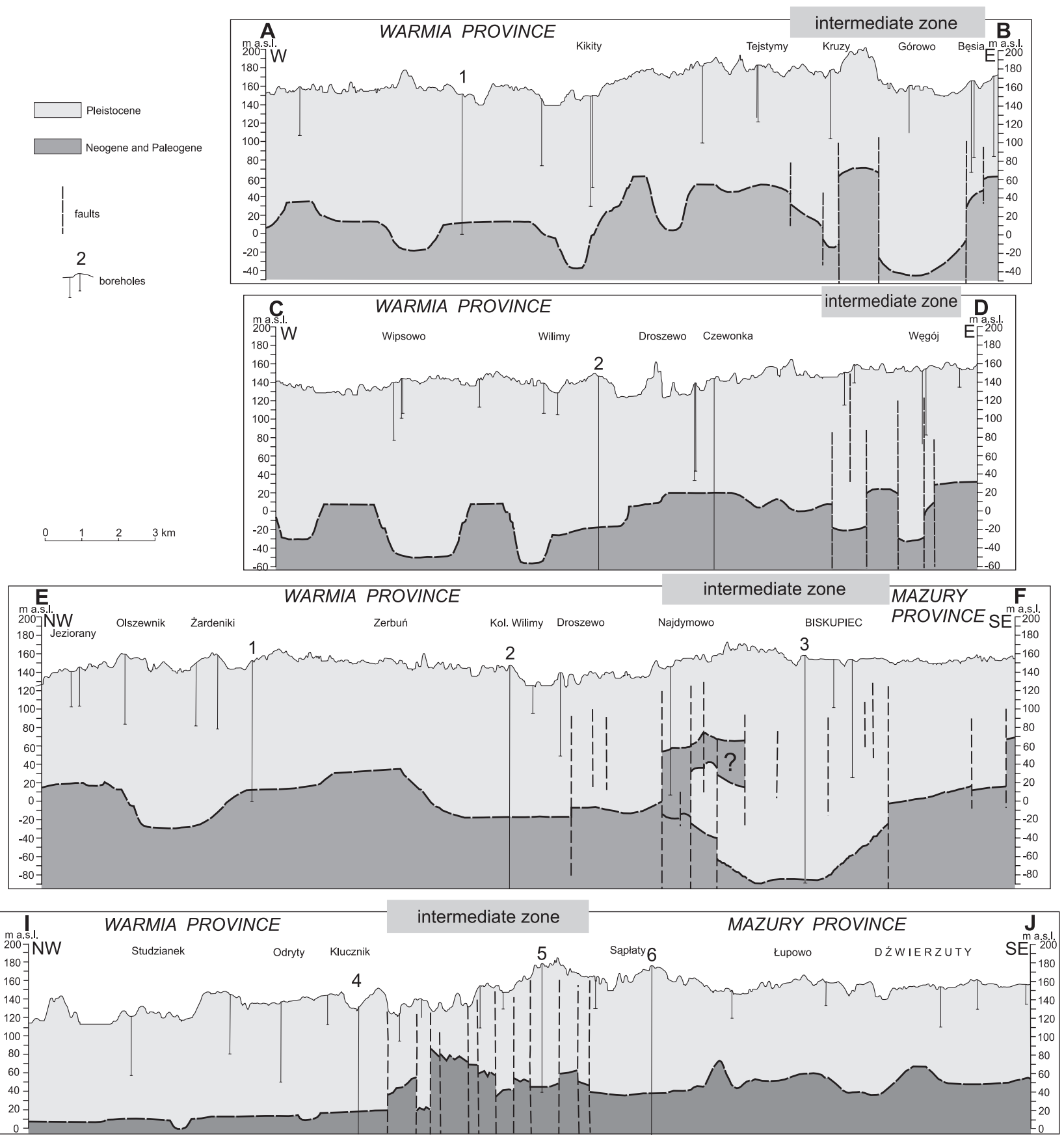

Fig. 3. Geological cross-sections through intermediate zone (see Fig. 2 for location). 
high-resolution shallow seismic-reflection profile (Dźwierzuty) (Figs. 4C, 5) was acquired from the Geofizyka Torun Company (A. Opak, unpublished). The seismic velocities were interpreted from unpublished seismic surveys and from deep boreholes in the Warmia region, so that a depth-converted version of the profile was obtained. The geological interpretation and depth correction of the succession down to the top-Cretaceous were based on data from boreholes 4,5 and 6 , all drilled along this profile. The stratigraphical interpretation of the pre-Palaeogene was based on archival data from boreholes. A $20-\mathrm{km}$ long geoelectrical sounding profile (70 SGE) was run by the Bipromel Company (T. Okrasa, unpublished) along line I-J. The profile was interpreted for its lithology and geological structure (Fig. 4A). Another geoelectrical profile was run along cross-section E-F. Two additional, crossing geoelectrical profiles were run in the Biskupiec region A. Jagodziński, B. Jagodziński \& R. Kalitiuk, unpublished Geoserwis data).

Drilling, seismic and geoelectrical data, as well as interpretation of gravity anomalies were used for the construction of the geological cross-sections (Fig. 3), in particular for the identification of the top-Neogene surface and of fault zones.

Photolineaments, visible on the 1:200,000 satellite maps (M. Graniczny \& S. Doktór, unpublished), and gravity-lineament maps ( $R$. Kucharski, unpublished) were used for a structural analysis.

\section{Lithology and structure}

The palaeogeographic provinces of Warmia and Mazury are separated by an intermediate area that is recognizable by its well pronounced postglacial morphology. Geophysical investigations and borehole analyses (especially from six wells drilled in the cental part and on both sides of the intermediate zone) have provided much information on the lithology, stratigraphy and geological structure of these three units and their mutual relationships. Details are presented elsewhere in this issue (Morawski, 2009d-this issue; Słodkowska, 2009-this issue).

\section{Pre-Cenozoic}

East of the intermediate zone is the MazurySuwałki Anteclise. The crystalline basement is located there at a depth of approx. $1.5 \mathrm{~km}$ and the sedimentary cover is reduced in thickness (the entire Palaeozoic is absent). In the West, the Peribaltic Syneclise occurs; the surface of its crystalline basement descends westwardly and the thickness of the sedimentary cover increases from 2 to $5 \mathrm{~km}$. The Lower Palaeozoic of the Peribaltic Syneclise was folded before the Arenig (Middle Ordovician), during the Caledonian orogeny. It is overlain by Late Palaeozoic and Mesozoic sediments. The Peribaltic Syneclise is bordered in the East by the Napiwoda-Purda-Ryn-Garbowo marginal trough, which runs N-S parallel to the slope of the crystalline craton (Fig. 1).

The intermediate zone coincides roughly with the sloping area of the crystalline craton and the marginal trough. Photolineaments show a similar direction It should be noted that the major photolineament, running from Pasym through Biskupiec, abruptly ends south of Korsze (Fig. 1) at the site where both the marginal trough and the slope of the crystalline craton turn east. Nearly parallel photolineaments appear at that place. The same change in direction is shown by gravity measurements.

The Dźwierzuty seismic profile (Figs. 4C, 5) was acquired across the intermediate zone along cross-section I-J (Fig. 2). The profile proves the occurrence of a vertical discontinuity zone (shotpoints 1200-1500) extending probably down to the crystalline basement. Data on the position of the crystalline basement are provided by the velocity model for the seismic profile (Fig. 6). The propagation velocity of the seismic wave, amounting to over $3500 \mathrm{~m} \mathrm{~s}^{-1}$ as observed in the lower portion of the profile's eastern end, may reflect either the nearby top of the crystalline craton or its immediate sedimentary cover located at a depth of more than about $1500 \mathrm{~m}$ (A. Opak, unpublished). This depth corresponds with that inferred from the interpretation of the relief of the top of the crystalline basement (Fig. 1). The velocity model illustrated in Figure 6 shows the location of the westward-dipping top of the crystalline craton, 


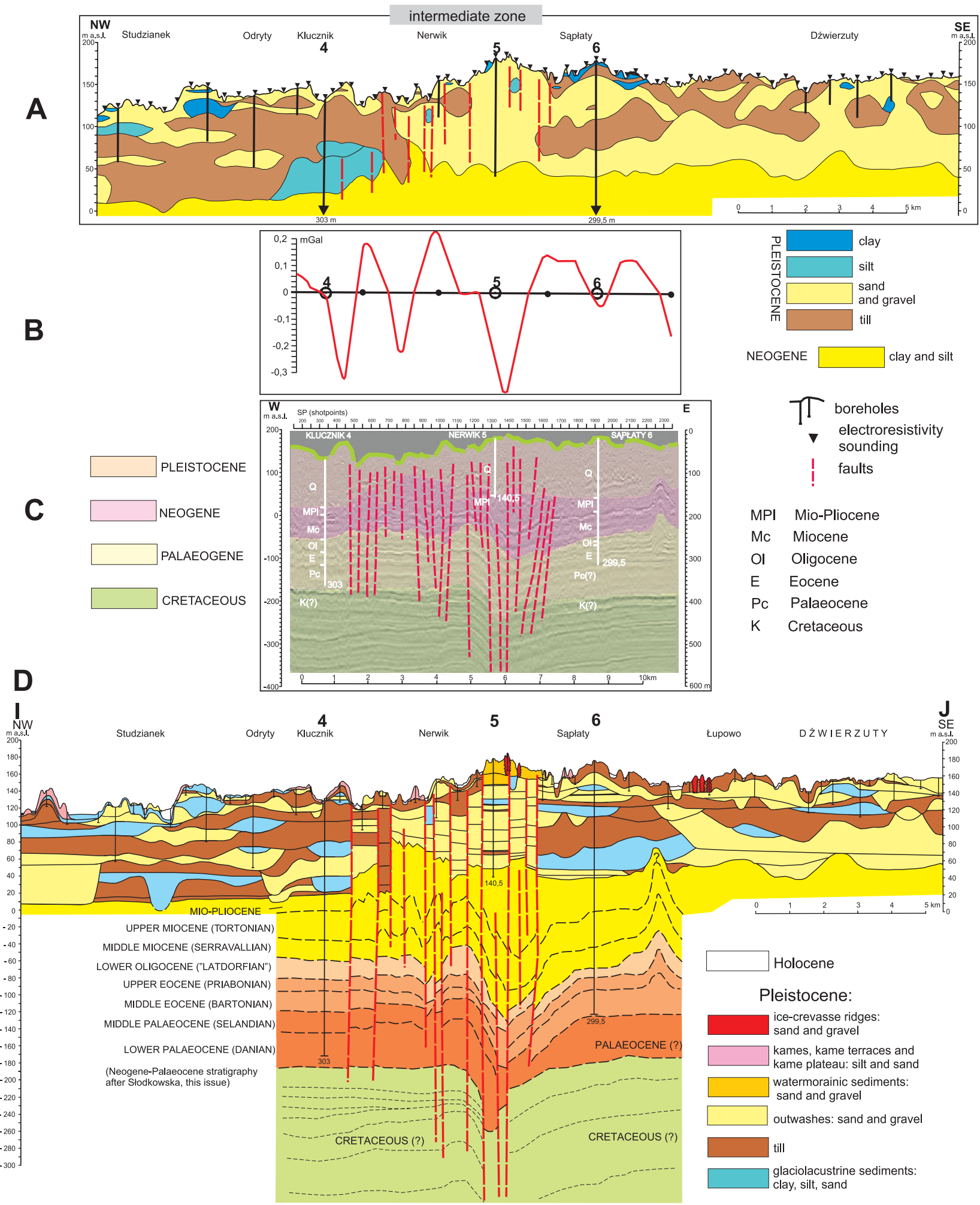

Fig. 4. Intermediate zone in the view of I-J cross-section (see Figs. 2, 3 for location): A - geoelecrical section (after T. Okrasa, unpublished); B - local gravity anomaly curve (after Z. Petecki \& J. Twarogowski, unpublished); C - seismic section (after A. Opak, unpublished); D - cross-section resultant of geophysical and geological analyses. 


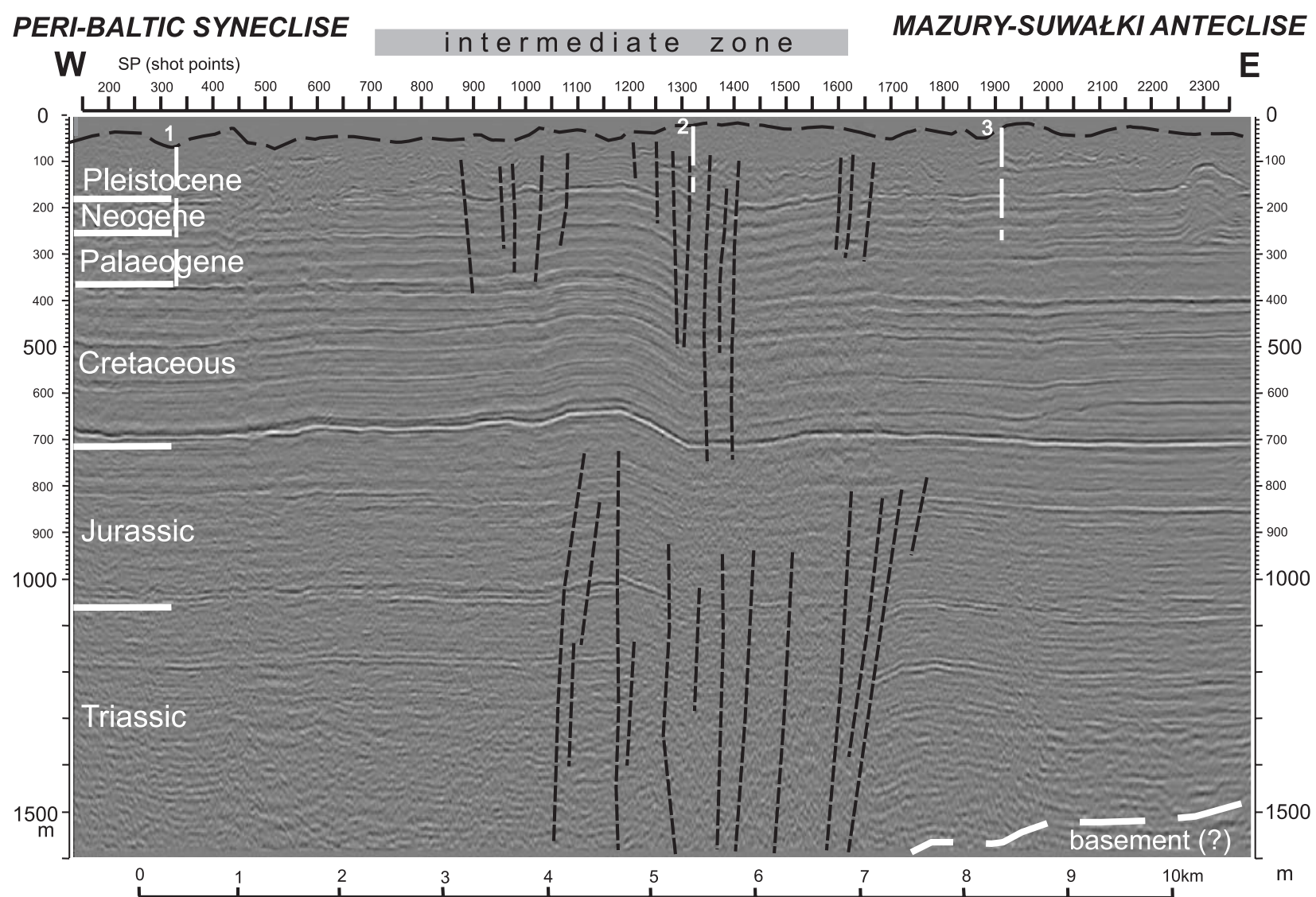

Fig. 5. Vertical discontinuities in the intermediate zone - the Dźwierzuty seismic section (after A. Opak, unpublished). Location of I-J cross-section on Fig. 2.

fully confirming its position and the location of the Napiwoda-Purda-Garbowo marginal trough.

Analysis of the Dźwierzuty seismic profile provides several structural data. Folding appears present along an area of some $2 \mathrm{~km}$ wide in the centre of the intermediate zone, between the top of the Neogene and a depth of approx. $1300 \mathrm{~m}$ (Fig. 5: shotpoints 1200-1300). The amplitude of the folds varies from $50 \mathrm{~m}$ within the Neogene deposits to $100 \mathrm{~m}$ at depths of 800$900 \mathrm{~m}$. This folding takes the form of a broad asymmetric flexure with a distinct bulge in its western part (Fig. 5: shotpoints 1100-1200). The amplitude of the fold decreases upwards (as in tectonic processes) but not downwards (which is characteristic of glaciotectonics). A similar bending (in the form of an oppositely directed flexure) is present at much greater depths (from 850 to around $1300 \mathrm{~m}$.) This flexure is also accompanied by a bulge of several metres long (Fig. 5: shotpoints 1650-1900).
These wide structures are closely related to discontinuity zones that can be referred to as near-vertical faults. Most of them are normal faults, but some are reverse faults (Fig. 5: shotpoints 1100-1200, depth 1000-1200 m). Two fault generations can be distinguished on the basis of the seismic profile. The older generation is present from probably the crystalline basement through the Jurassic, i.e. within the depth interval starting at approx. $1500 \mathrm{~m}$ and ending at 700-800 m. These faults fade out upwards like tectonic structures. The younger generation is present in the Cenozoic succession, down to a depth of $350 \mathrm{~m}$. The only place where the small-throw faults reach down to the Jurassic (about $700 \mathrm{~m}$ deep) is in the axis of the fold. These faults fade out downwards like glaciotectonic structures. However, it should be noted that the intermediate zone in its deeper part, beneath the Cretaceous shows the character of a tectonic graben, approx. $2 \mathrm{~km}$ wide. The graben infilling is probably strongly deformed, 


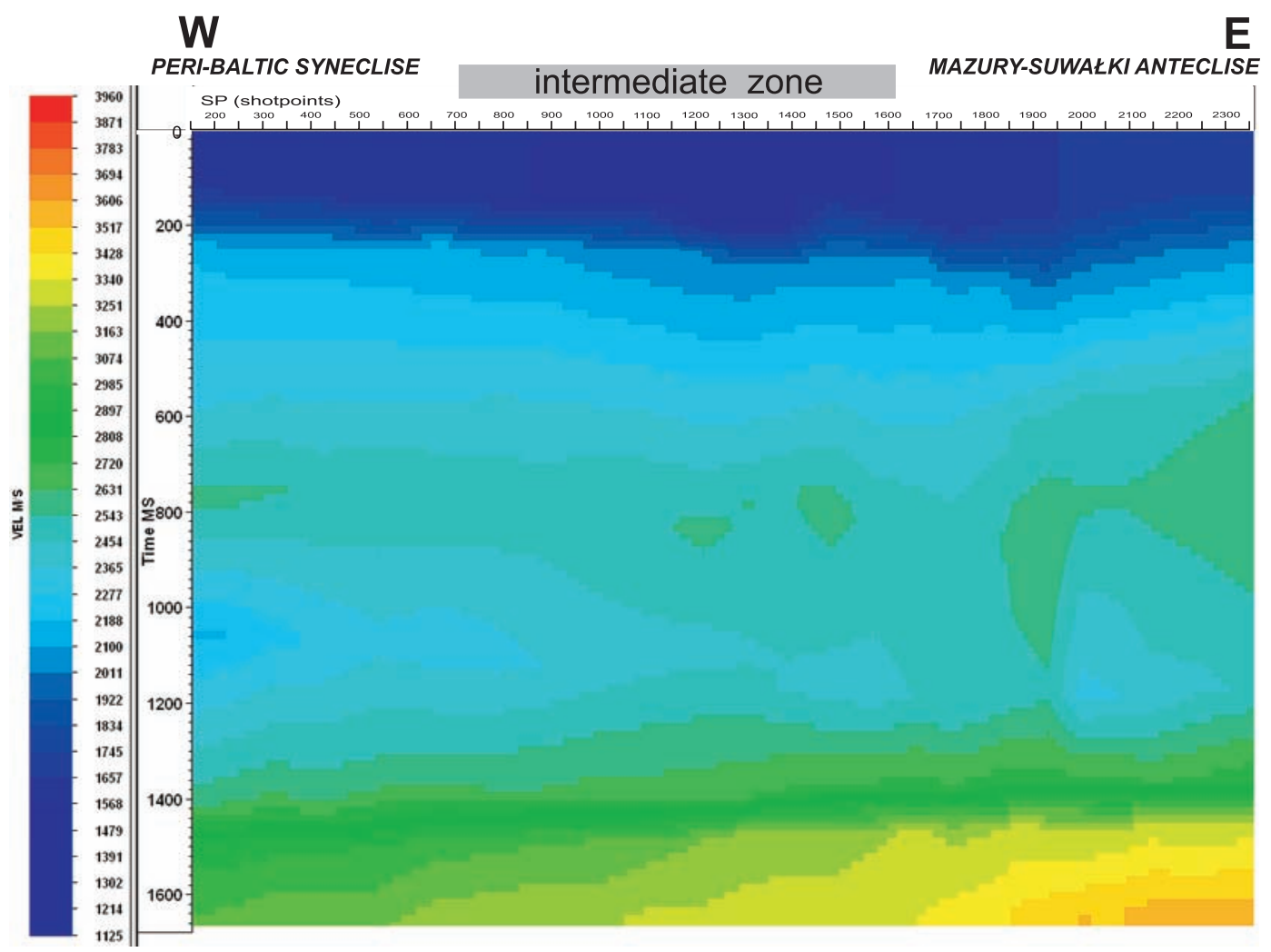

Fig. 6. Seismic profile Dźwierzuty - velocity model (by A. Opak, unpublished). See Fig. 2 for location.

as the strata in the seismic profile are mostly discontinuous.

The upper part of the Cretaceous west of the profile, at a depth of $370-500 \mathrm{~m}$ (Fig. 5) is interesting. The basal reflection clearly ascends eastwards towards the axial bulge, up to $70 \mathrm{~m}$. The overlying strata are discontinuous and wedge out eastwards. The thickness of this package decreases eastwards by about $40 \mathrm{~m}$, so that the axial bulge almost completely disappears at a depth of $370 \mathrm{~m}$. Higher up, the bulge is still visible, but its amplitude is much reduced. The sedimentary pattern suggests that the tectonic processes started during the Cretaceous or already during the Jurassic, and that they developed during several successive phases.

\section{Palaeogene and Neogene}

The intermediate zone between the Warmia and Mazury provinces was thoroughly investigated over a distance of approx. $45 \mathrm{~km}$. The boreholes, drilled in the study area within the zone and on its both sides, proved that the Pleistocene deposits overlie a clay and mud succession (Poznań Formation) assigned by Słodkowska (2009-this issue) to the MioPliocene.

Data from boreholes, geoelectric profiles, seismic profiles and the gravity anomaly map (Fig. 3) enable reconstruction of the top-Neogene (Fig. 7) and of geological cross-sections across the intermediate zone. They reveal that the top-Neogene in the Mazury province is remarkably flat and lies at an elevation of 40-60 $\mathrm{m}$ a.s.l. (cross-section I-J in Fig. 3). In the Warmia province, the top-Neogene is situated a few tens of metres lower, at about 0-20 $\mathrm{m}$ a.s.l. (Fig. 7; cross-section I-J in Fig. 3). This surface is highly varied - the differences in elevation of the top-Neogene are up to $40 \mathrm{~m}$ (Fig. 3: cross-sections A-B, C-D, E-F). In the intermediate zone, the top-Neogene shows a considerable relief, from $90 \mathrm{~m}$ a.s.l. in cross-section I-J (Fig. 3) to approx. $90 \mathrm{~m}$ b.s.l. in cross-section E-F (Fig. 3).

The top-Neogene along cross-section I-J (Fig. 3 ) in the area situated west of the intermediate 
zone occurs $20 \mathrm{~m}$ lower than east of this zone (see boreholes 4 and 6 in Fig. 3 and Fig. 4D). The height difference diminishes downwards because it is compensated by a reduction in thickness of the Mio-Pliocene succession. At a depth of 800-900 m (probably Jurassic), a trend opposite to that at the top-Neogene is found: the same reflections (strata) in the western part are up to about $50 \mathrm{~m}$ higher than in the East (Fig. 5). The top-Neogene in the centre of the intermediate zone (borehole 5 in Fig. 3 and Fig. 4D) is about $10 \mathrm{~m}$ higher than in the eastern area, and over $30 \mathrm{~m}$ higher than in the western part.

The results of geophysical investigations, especially geoelectrical profiling, show that a local block uplift may have occurred in the area and that the top-Neogene even reached a position of $90 \mathrm{~m}$ a.s.l., i.e. approx. $75 \mathrm{~m}$ higher than the top-Neogene in the West (Fig. 4A and 4D). At a depth of 150-200 m, the seismic profile shows an opposite situation in the central zone: the top-Miocene has subsided here by about $60 \mathrm{~m}$ in comparison to the fairly even surface on both sides of the zone (Fig. 4C and 4D).

An entirely different structural situation occurs in the intermediate zone at Biskupiec along cross-section E-F (Fig. 3). The intermediate zone was examined by three geoelectrical profiles that cross one another (Figs. 2, 7). They show that either a 5-6 km wide depression exists or a short, E-W orientated tectonic graben (the Biskupiec graben). These profiles also reveal a number of vertical discontinuity surfaces cutting the Pleistocene and Neogene. The top-Neogene occurs at an altitude of 95 $\mathrm{m}$ b.s.l. in the centre of the Biskupiec graben, i.e. $100 \mathrm{~m}$ lower than on average in this region (Fig. 7; see borehole 3 in Fig. 3). In the NW, near Najdymowo, the top-Neogene can locally be elevated in blocks or due to glaciotectonic diapiric thrusting up to $70 \mathrm{~m}$ a.s.l., so that the local relief can exceed $165 \mathrm{~m}$. The top-Oligocene was found in a borehole drilled near Najdymowo at $50 \mathrm{~m}$ a.s.l., i.e. $110-120 \mathrm{~m}$ higher than in boreholes 4 and 6 (Fig. 4D). TheBiskupiec graben represents probably a local widening of the intermediate zone (Figs. 2, 7). It is worth noting that this widening follows deep basement structures; the Napiwoda-Purda-Ryn-Garbowo marginal trough, which runs along the crystalline basement slope, widens significantly just at this place and slightly changes its direction in this area (Fig. 1).

A separate problem is the glaciotectonic deformation in the intermediate zone between the discontinuities, and in its neighbourhood. The seismic profile reveals a glaciotectonic fold east of the central zone. The fold probably involves Early Pleistocene, Neogene, Oligocene and Eocene deposits (Figs. 4C, 4D; Fig. 5: shotpoints 2250-2350). The disturbances die out downwards in a way that is characteristic of glaciotectonic structures, and they reach a depth of $280 \mathrm{~m}$. The fold is slightly inclined westwards. In its lower part, a short overthrust may exist that indicates a westward oriented stress.

\section{Pleistocene}

Pleistocene deposits cover the whole study area. Their thicknesses, as found in boreholes in the Warmia province, vary from $113 \mathrm{~m}$ to 165 $\mathrm{m}$. Geophysical investigations prove, however, that the maximum thickness can be about 200 $\mathrm{m}$ (Fig. 3). In the Mazury province, the thickness of the Pleistocene ranges from 80 to 140 $\mathrm{m}$. In the intermediate zone, large variations in the thickness of the Pleistocene occur: from 135 $\mathrm{m}$ in Nerwik (borehole 5: Fig. 4) to $243 \mathrm{~m}$ in Biskupiec (borehole 3: Fig. 3). Geoelectrical investigations show that the thickness can locally be less (to about $40 \mathrm{~m}$ ), probably due to glaciotectonic deformation and diapiric upthrusts of Neogene deposits. The base-Pleistocene in Warmia occurs generally deeper than in Mazury (Fig. 7). The various Pleistocene successions also lie at lower altitudes.

Lithological and stratigraphical investigations revealed many differences between the Pleistocene profiles of both provinces. These investigations, complemented with a geomorphological analysis, proved also differences in the sedimentary conditions between these two regions, during both glacials and interglacials (Morawski, 2009d-this issue).

The Pleistocene succession of the intermediate zone is highly variable. The dominant li- 


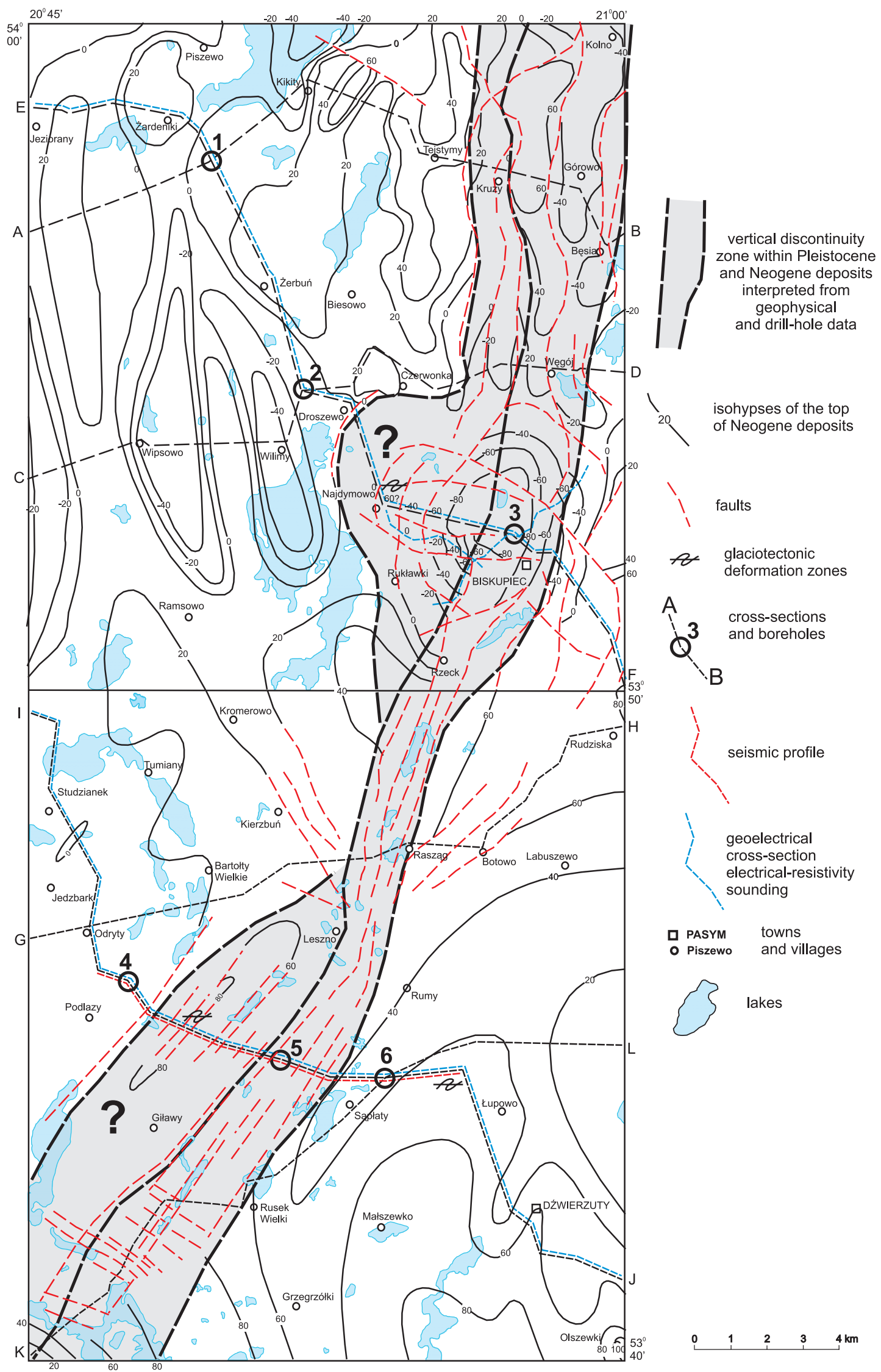

Fig. 7. Morphology of the Neogene-top surface with interpreted faults. 
thology of the southern and central parts of the area is sand/gravel/boulder with thin intercalations of glacial diamicts (borehole 5 in crosssection I-J: Fig. 4 D). This succession shows that an interlobe zone with dominant crevasse-fill sedimentation developed in between the two provinces. Probably interlobe zone was formed along almost the same line during the successive Pleistocene glaciations. The sand/gravel crevasse-fill sediments of the intermediate zone are clearly visible in the geoelectrical profile as high-resistivity deposits (see A in Fig. 4). This zone of approx. $4 \mathrm{~km}$ wide has boundaries at both sides that are interpreted as near-vertical discontinuity zones.

The intermediate zone is expressed on the gravity-anomaly map as a negative-anomaly belt (Fig. 2). The occurrence of zones with negative anomalies can be interpreted as the presence of thick sand/gravel units. A similar effect is produced by near-surface Neogene deposits. Zones with positive anomalies occur at both sides of the negative-anomaly zone. The positive anomalies can be interpreted as either depressions in the top-Neogene or an increased thickness of the Pleistocene, in particular of thick tills. It is proven by both geoelectrical research and borehole data. A typical example of such a situation is found in the Rasząg region where, along cross-section G-H (Fig. $2)$, the intermediate zone is composed of thick sand/gravel units (zone of negative anomaly). To the East, a vertical contact exists with a till unit that is locally up to some tens of metres thick (zone of positive anomaly). The increased till thickness occurs only along a belt (up to 1 $\mathrm{km}$ wide) that coincides with the width of the positive anomaly. Similar but weaker positive anomalies occur within a belt extending to the West. An analogous situation is present in the northern part of the intermediate zone between Wygój, Bęsia and Kolno (Fig. 2). The intermediate zone is bordered in this area by a prominent zone of negative anomaly that is, in turn, accompanied, particularly at its eastern side, by a clear zone of positive anomalies.

The small distances between positive and negative anomalies confirm the occurrence of vertical discontinuity zones between the thick till unit and the sand/gravel crevasse infillings of the intermediate zone. They also support the presence of blocks with different heights of the top-Neogene (Figs. 3, 7), separated by vertical discontinuities. The elongated blocks follow the orientation of the intermediate zone, extending NNE-SSW and N-S in the northern area (Fig. 7). Both geophysical investigations and drilling data suggest that the intermediate zone is, in some areas, transected by transverse faults that seem to be limited in extent to the zone's width (see Fig. 7).

The differences between the two provinces and the intermediate zone is also expressed in the topography, which developed during the last ice-sheet retreat. The glacial upland of the eastern area is composed of tills with small depositional landforms. In the western area, with its some $20-40 \mathrm{~m}$ lower altitude, glaciolacustrine depressions and numerous tunnel valleys (partly occupied by lakes) dominate the landscape. The most characteristic feature of this western area is the occurrence of abundant kames, kame terraces and plateaus that represent glacial landforms associated with both an irregular ice surface and the presence of deadice blocks.

The intermediate zone is well expressed by its topography. It shows itself as a belt of flowtills and glaciofluvial deposits with numerous elongated crevasse-fill landforms that have the same N-S orientation as the zone itself (Fig. 2). Geomorphological and lithofacies analyses of the intermediate zone lead to the conclusion that this is an interlobe area that extended between the Mazury and Warmia lobes of the last ice sheet (Fig. 1).

A slightly different situation is present in the southern part of the study area (Rusek Wielki-Giławy cross-section, K-L: Fig. 2), where a coarse-grained crevasse infilling is up to some tens of metres thick. A deep tunnel valley, now occupied by Lake Giławskie more to the West (Fig. 2), runs parallel to the crevasse sediments. Further West of the tunnel valley, a belt of kame hills occurs. The parallel occurrence of elongated kames, a deep tunnel valley and a kame belt in the same area proves a multi-stage development of NE-SW-oriented depressions and cracks in the ice mass. It cannot be excluded that this situation is partly or 
even entirely due to the vertical movements of blocks during the last glaciation.

A completely different Pleistocene succession occurs in a wide depression of the intermediate zone near Biskupiec: the Biskupiec graben (cross-section E-F in Fig. 3). The Pleistocene deposits in borehole 3 are extremely thick (243 m). The Early Pleistocene here consists of deposits that accumulated in repeatedly ice-dammed lakes, and has a total thickness of $80 \mathrm{~m}$ (Morawski, 2009d-this issue).

In the southern part of the study area between Pasym and the Leszno-Rumy line, the intermediate zone is elongated in a NE-SW direction (Fig. 2). Further North, this direction changes to NNE-SSW, as expressed by high hills that extend as far as the Biskupiec region. At the site of the direction change, a NW-SE running zone (Kromerowo-Kierzbun-Leszno) of minor crevasse-fill landforms branches off the interlobe zone on the western side (Fig. 2).

The Dźwierzuty seismic profile shows a number of vertical discontinuities in the interlobe area, which disturb the reflections that indicate the boundaries between lithological units within the near-surface Pleistocene (Figs. $4 \mathrm{C}, 5)$. The units interpreted in this high-resistivity zone as tills, which are visible in the geoelectrical profile and which are continuous on both sides, end also against vertical discontinuities (Fig. 4 A). Additional information on the discontinuity surfaces is provided by the gravity-anomaly map (Fig. 2), which shows that the intermediate zone is a belt of local negative anomalies surrounded at both sides by local positive anomalies. The short distance between the positive and negative anomalies suggests geological structures with steep edges or true discontinuity zones. These discontinuities are indicated as faults in both the map of the top-Neogene (Fig. 7) and the cross-sections (Fig. 3).

\section{Tectonic development of intermediate zone}

The results of seismic, geoelectrical, gravity and drilling investigations of the intermediate zone suggest vertical discontinuity surfaces in areas segmented into blocks. It seems that the discontinuity zones are not separated from one another by single fault planes, but rather by fault zones or/and steep flexures. The various investigations of both the intermediate zone and its adjoining areas provide data for a discussion on the processes that took place and their structural effects.

\section{Pre-Pleistocene}

Tectonic processes that were active before the Pleistocene can be inferred mainly from the Dźwierzuty seismic profile and the boreholes drilled along it. It might be hypothesized that the zone of the East European craton slope with the accompanying marginal trough were prone to tectonic processes, mainly in the form of vertical movements of tectonic blocks (Fig. 8A). Vertical movements can be deduced from the presence of the early-generation faults which were mentioned above to have been identified in the seismic profile (Fig. 5). They occur within the crystalline basement and extend up to the Cretaceous, then die gradually out upwards.

The positive structure observed West of the flexure in the intermediate zone is transected by reverse faults beneath a depth of $1 \mathrm{~km}$. It gradually fades away in an upward direction, but is traceable as far up as the top-Neogene. This suggests that the structure was essentially formed as a result of Pleistocene tectonics. However, the unconformable sedimentary pattern in the upper part of the Cretaceous, which reduces the amplitude of the bulge in the western flank of the flexure, suggests several stages of tectonic activity, which probably started during the Cretaceous or perhaps already during the Jurassic. It is therefore likely that glacio-isostatically induced movements related to the Pleistocene ice-sheet advances and retreats could take place because of reactivation of older tectonic structures in the area above the slope of the crystalline basement between the Mazury-Suwałki Anteclise and the Peribaltic Syneclise.

An important issue is the reconstruction of the stress fields. The early-generation faults 

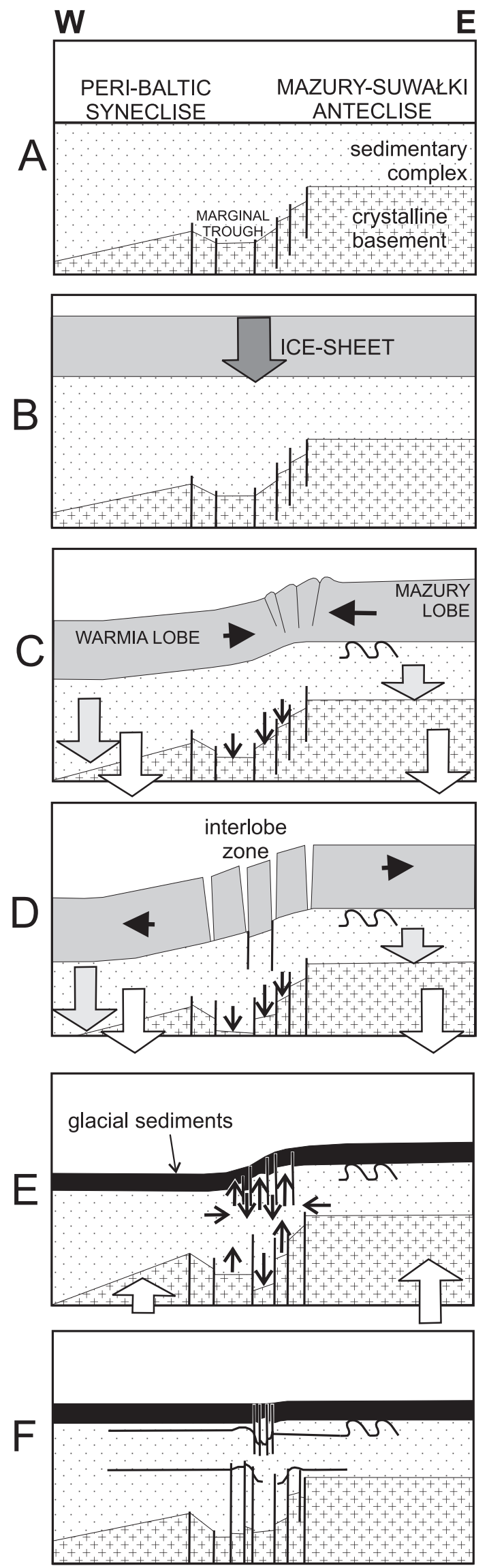

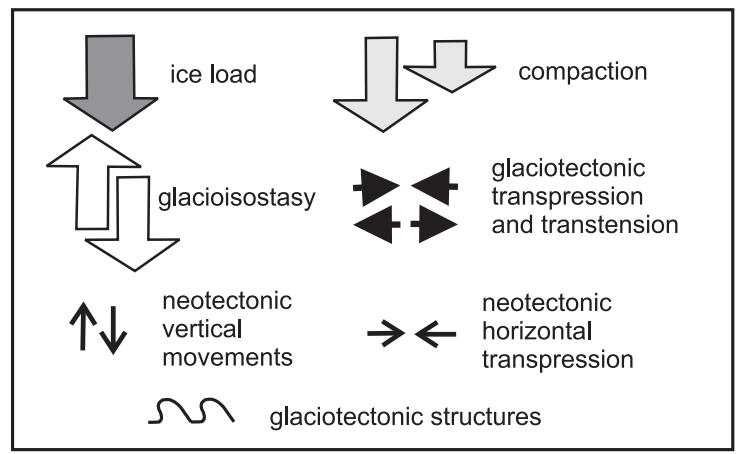

Fig. 8. Development of intermediate zone between Peribaltic Syneclise and Mazury-Suwałki Anteclise: A - before ice-sheet advance; B - ice-sheet advance; D - glaciotectonic transpression, compaction of sedimentary cover, glacioisostasic and neotectonic movements; E deglaciation: relaxation, neotectonic movements and traspression; F - present-day stage.

clearly suggest activity of a tectonic graben of 2 $\mathrm{km}$ wide, in which the primary structure of the sedimentary succession was almost entirely destroyed (Fig. 5). The downward flexuring on both sides of the graben suggests a subsidence that can be estimated as approx. $100 \mathrm{~m}$. The graben therefore is likely a tensional structure related to either a westward downwarping of the deep basement or subsidence of the marginal trough. On the other hand, the positive structures at both sides of the graben suggest E-W oriented horizontal compression. Moreover, the positive structure at a depth of over 1 $\mathrm{km}$ in the western area is cut by a number of reverse faults and clearly shows folding, which is indicative of compression.

The strata in the tectonic graben that are less than $700 \mathrm{~m}$ deep are continuous, as illustrated by the reflection at this depth (Fig. 5). The well developed bulge on the western side and a small depression in the graben's axis result in an altitude difference of the layer that is responsible for the strong reflection of about 80 $\mathrm{m}$, which is a measure for the compression. It may therefore well be that the graben formed by downwarping of the intermediate zone. Grabens under compressional stress are, however, easily affected by inversion uplift. The graben structure may therefore have formed during a number of stages, each with its own stress pattern. 
The positive structures at both sides of the graben are asymmetric, because they show a stronger flexural bending towards the axis of the graben. This suggests a transpressional process if the strike-slip stress regime was oriented parallel to the graben axis. Strike-slip movements along the margin of the crystalline basement are probable because such a strike-slip regime is typical of NE Poland; this is evidenced by seismic activity in the Kaliningrad region (Wiejacz, 2004; Zuchiewicz et al., 2007).

A faultless zone of continuous strata occurs above the graben with the early-generation faults that fade out upwards at a depth of $700 \mathrm{~m}$. The later-generation faults occur in the Cenozoic to a depth of $350 \mathrm{~m}$ (Fig. 5). Within this $0-350 \mathrm{~m}$ interval, the vertical discontinuity zone in which most primary structures have been destroyed, is only approx. $600 \mathrm{~m}$ wide, which implies that it is three times narrower than the underlying graben. The flexure bounding the graben to the East also dies out upwards at a depth of $700 \mathrm{~m}$. Such a structural image suggests genetic and temporal distinction of two complexes: a Triassic-Jurassic tectonic complex (lower) and a Cenozoic neotectonic complex (upper). The western flexure is, however, identical for both units: it is uniform in all units up to the top-Neogene and even partly in the Pleistocene, although it fades out upwards.

The above suggest a vertical discontinuity zone in the intermediate zone between the Peribaltic Syneclise and the Mazury-Suwałki Anteclise. Its configuration is undoubtedly constrained by the deep geological structure and possibly associated with the orientation of dislocations in the crystalline basement (Fig. 8). The discontinuity zone evolved during several stages. The tectonic activity included not only displacements of vertical blocks resulting in the formation of a discontinuity zone, but also horizontal compression.

The timing and vertical extent of the various structural processes has been investigated by Słodkowska (2009-this issue) by means of lithological and stratigraphical analyses of the entire Neogene and Palaeogene. The investigated samples came from boreholes 4 and 6 in the Dźwierzuty seismic profile on both sides of the intermediate zone (Fig. 4D). The investigations proved that similar conditions occurred at both sides of the intermediate zone from the Late Cretaceous to at least the latest Miocene. The sediments dating from this interval have the same lithology and thickness at both sides of the intermediate zone. Hence, it can be inferred that the whole area, probably including the intermediate zone, was tectonically stable from the Late Cretaceous to the Pleistocene. It should be mentioned in this context that the differences in thickness of the Mio-Pliocene clays/muds in cross-section I-J (Fig. 4D) have no meaning for an interpretation of the tectonic processes because they have undergone erosion and glacial exaration during the advances of the oldest Pleistocene ice sheets. The MioPliocene clays/muds are prone to glaciotectonic deformation, including upthrusts (and local diapirism). This resulted in locally manyfold increases in thickness of the deposits.

\section{Pleistocene}

All the geomorphological, lithological and stratigraphical facts indicate cyclic upward and downward movements both within and beside the intermediate zone. The vertical movements were larger on the western side (Fig. 8) which caused differences in lithologies of the Pleistocene between the two provinces. The stronger vertical tectonic movements in the western province resulted in both numerous stratigraphic gaps and different elevations of corresponding deposits (Morawski, 2009dthis issue). Structural analysis of the Pleistocene close to the intermediate zone shows a generally lower position of the same units at the western side (Fig. 4D), probably due to at least two processes related to the advances and retreats of the Pleistocene ice sheets.

In the first place, the subsidence of the prePleistocene/Pleistocene boundary was probably larger because of stronger compaction of deposits in the western province than in the eastern province (Fig. 8C,D). This is suggested particularly by the considerable difference in thickness of the sedimentary cover that overlies 
the crystalline basement. If both the ice thickness (and therefore the pressure exerted on the basement) and the basement permeability (and thus its susceptibility to subglacial drainage) were similar in both the areas, the compaction magnitude of the basement sedimentary series was conditioned by the thickness of these rocks (Boulton \& Dobbie, 1993). The compaction of the deposits in the western region (where the deposits are twice or even three times as thick as in the eastern region) was undoubtedly much larger. One might discuss whether the compaction of the deposits, in particular of the sandy/gravelly and clayey deposits, was an irreversible process, but this question is considered out of scope here.

In the second place, the much thicker sedimentary cover of the Peribaltic Syneclise than that above the crystalline craton of the MazurySuwałki Anteclise suggests that the former area was subjected to permanent and strong subsidence. The dynamic difference between these regions is also expressed by their structural characteristics. Undisturbed sedimentary successions on the eastern side overlie a relatively flat surface of the crystalline basement. On the western side, in contrast, a strongly disturbed sedimentary succession rests upon the crystalline basement that steeply slopes westward, indicating that the area was tectonically active. It thus seems that the stress induced by the weight of successive ice sheets caused much more significant glacio-isostatic movements in the western province (Fig. 8C,D).

The intermediate zone was probably predisposed to undergo vertical movements. The gradual downward diminishing of the amplitude of displacements in the later-generation zone and the fold structures proves that they were induced by stresses exerted by the successive advancing ice sheets. The presence of corresponding sedimentary units at altitudes ranging from 250 to $300 \mathrm{~m}$ suggests that 50 $m$ was the vertical range of persistent effects of glaciotectonic movements. Tectonic movements of blocks, induced by ice sheets, probably occurred in the intermediate zone throughout the Pleistocene (Fig. 8E). These movements along this interlobe zone were predisposed both by the pre-existing tectonic mobility in the slope zone of the crystalline basement accompanied by the marginal trough and by the westward increasing thickness of the sedimentary cover. Vertical movements were accompanied by strike-slip displacements, resulting in a transpressional regime along the intermediate zone (Fig. 8E).

Both glacio-isostatic movements and different degrees of compaction probably caused phases of stronger downwarping of the basement on the western side, and thereby cracking of the ice sheets, resulting in the formation of a succession of interlobe zones along the line of maximum ice extent (Fig. 8D). Thus, the Pleistocene tectonic movements were triggered by advances and retreats of the successive ice sheets, but their locations - always along the same linear zone - were constrained by preexisting structural features of the deep basement.

The interpretation of the structural setting and origin of the intermediate zone is based mainly on data obtained along cross-section I-J, where the Dźwierzuty seismic profile is situated. However, structural analysis along the cross-section lines (Fig. 3) reveals variations in the structures and thus differences in the processes that took place in the various parts of the zone. A particularly well explored area is located in the Biskupiec region, which was examined by means of three geoelectrical profiles and one borehole 3 drilled in the centre of the intermediate zone (Fig. 3). A depression appears to occur in this area. It has the shape of a short, E-W orientated, tectonic graben (Fig. 7) and was formed as a result of subsidence that continued throughout almost the whole Pleistocene. Its depocentre was situated in the centre of the intermediate zone.

The Pleistocene at its base of ice-dammed lacustrine sediments and interglacial deposits that are present only within the graben. This suggests that subsidence increased during interglacials. This is surprising at first sight, because interglacials are characterised in general by uplift. The explanation is reactivation of old structures in the deep basement, resulting in blocks with different tectonic behaviour. The shape and configuration of the marginal trough is interesting in this context, because 
the trough changes its direction and considerably widens in the Biskupiec region. This contrasts with the relief of the top of the crystalline basement in this region (Fig. 1). Probably it was an area of local subsidence of the crystalline basement during the Pleistocene. Geophysical and drilling data suggest that the intermediate zone also considerably widens in the Biskupiec region (Figs. 2, 7). A diapir-like upthrust or a block of Neogene deposits that was uplifted to $70 \mathrm{~m}$ a.s.l. (= $165 \mathrm{~m}$ higher than in the centre of the Biskupiec graben) is present in the Najdymowo region (the western margin of the graben) (Fig. 3). In the graben's centre, reworked Miocene and Oligocene sediments have been found in borehole 3 at an elevation of $80-100 \mathrm{~m}$ a.s.l. This proves that the local uplift here was even larger. The vertical glacioisostatic movements in the intermediate zone must even have been larger than estimated by Uścinowicz (2003), who mentioned approx. $120 \mathrm{~m}$ after the last ice-sheet retreat (e.g., in the southern Baltic Sea).

The glaciotectonic deformation, both within and aside the intermediate zone, poses a problem. East of the intermediate zone, a wide fold in Eocene through Early Pleistocene deposits occurs (Figs. 4C, 5). This asymmetric fold is slightly inclined westwards, presumably with an overthrust in its lower part, suggesting a westward-oriented horizontal stress, approximately perpendicular to the intermediate zone (Fig. 8C). The fold dies out downwards; seismic reflections beneath a depth of $280 \mathrm{~m}$ indicate undisturbed strata. Such a structure is characteristic of glaciotectonic deformation, and these observations specify the vertical range of glaciotectonic processes. Glaciotectonic deformations in the Warmia region reach a similar depth $(250 \mathrm{~m}$, locally $300 \mathrm{~m}$, which depth is equivalent to $120 \mathrm{~m}$ b.s.l.), suggesting that the depth of $250-300 \mathrm{~m}$ is the maximum depth where dynamic effects can be found of the stress that the Pleistocene continental ice sheets here exerted on their basement. The deformations involve the top part of the Oligocene, as well as the Neogene and Pleistocene, as far as older than the Odranian glaciation, and formed as a result of cylindrical shear generated by ice stress (Rotnicki, 1976).
Cross-section I-J (Fig. 4D) shows that the Neogene and Lower Pleistocene of the intermediate zone were upthrusted or uplifted as blocks, whereas the older deposits became downwarped. In the Najdymowo region (cross-section E-F in Fig. 3), the Neogene and Palaeogene were also uplifted, as a block or upthrust, to an altitude of commonly $70-80 \mathrm{~m}$ a.s.l. (locally even much higher) to form a diapiric structure. These data suggest that the Pleistocene vertical movements of blocks were accompanied by an E-W - oriented horizontal compressional regime. This could be the above-mentioned process of transpression. Some of the small E-W running faults can have a strike-slip nature. This may require further research. However, it cannot be excluded that these faults, too, are due to glaciotectonic processes: such compressional structures may have formed as a result of two large ice lobes meeting each other along the interlobe zone (Fig. 8C). The formation of the above-described asymmetric fold must be ascribed to the same processes of glaciotectonic compression. Additional arguments for the occurrence of glaciotectonic upthrusts are the gravity anomalies and borehole data from the areas at both sides of the intermediate zone (Fig. 2). The small distance between positive and negative anomalies suggests the occurrence of vertical discontinuity zones between lithologically different units. Thick tills occur along the sandy/gravelly interlobe zone (Morawski, 2009d-this issue). During its maximum extent, the Warmia ice-sheet lobe probably not only flowed southwards faster, but also exerted pressure upon the Mazurian lobe. On the western side, the Warmia lobe advanced $8 \mathrm{~km}$ further to the South than the Mazury lobe (Fig. 1). The Warmia lobe could temporarily behave as a much faster ice stream at the contact with the Mazury lobe. Therefore, the interlobe zone acted during the maximum activity of the Warmia ice-sheet lobe as a left-hand obliquenormal-slip fault zone. The nature of slip fault zone is also proven by the presence of adjacent zone near Leszno where crevasse deposits approach the interlobe zone at an angle of $45^{\circ}$. This zone is wider near the interlobe zone and gradually dies out with increasing distance to the interlobe area (Fig. 2). It can be considered an effect of tension feather fractures (Riedel shear 
fractures) under a strike-slip shear regime. The two lobes meeting each other may have caused the cumulation of ice masses on both sides of the interlobe zone (Fig. 8C). The upthrusts, folds and increased till thickness might thus result from glaciotectonic transpression caused by the movement of the two ice lobes during their maximum extent.

As the Warmia lobe was subsiding towards the West, the compression upon the interlobe zone decreased. A tensional regime controlled the pre-deglaciation phase (Fig. 8D). During the deglaciation elongated crevasse-fill landforms with N-S orientation (Fig. 2) were formed within the interlobe zone. The tensional regime in the area West of the interlobe zone during deglaciation became reflected by numerous kames developed in gradually growing depressions in the ice, and subsequently between dead-ice blocks (Morawski, 2009d-this issue).

After the ice-sheet retreat, glacio-isostatic rebound started (Fig. 8E). As mentioned above, the elevations of the top-Neogene and of correlatable Pleistocene units in the area West of the intermediate zone were on average some $20 \mathrm{~m}$ less than in the East, possibly due to incomplete compensation of subsidence that took place during the ice advance. The lower position of correlatable units in the West might also be ascribed to more compaction.

\section{Conclusions}

The zone between two large tectonic units in NE Poland (the more eastern Mazury-Suwałki Anteclise characterised by an elevated crystalline basement and a thin sedimentary cover, and the more western Peribaltic Syneclise characterised by a much lower crystalline basement and a thicker sedimentary cover) coincides with the westward-inclined slope of the crystalline craton that is accompanied by a parallel marginal trough with a roughly NNE-SSW direction. This zone was probably long characterised by tectonic activity, but it was stable from the Late Cretaceous to the Pleistocene. Vertical downward movements started in the Pleistocene as a result of loading by continental ice sheets and glacioisostatic rebound occurred during ice retreat.
During Weichselian the intermediate zone between the eastern and the western provinces was an interlobe zone, as expressed by the topography over a distance of approx. $80 \mathrm{~km}$. Interlobe zones of earlier Pleistocene ice sheets developed along approximately the same line.

Vertical tectonic movements that shaped the interlobe zone during the Pleistocene differed from place to place. Strong subsidence in deep tectonic grabens was accompanied by the uplift of blocks in adjacent areas. These movements, which were probably related to mobility of blocks of the crystalline basement along the craton slope, involved vertical movements that exceeded $160 \mathrm{~m}$.

Two generations of vertical fault zones have been identified within the intermediate zone; they run commonly more or less N-S, which is consistent with the elongation of the zone. The later-generation faults cut the sediments down to a depth of 300-600 m. This faulting can be related directly to glacio-isostatic processes. The earlier-generation faults occur from a depth of approx. $700 \mathrm{~m}$ down to the crystalline basement. These faults were formed due to glacio-isostatically induced tectonic movements along a zone of weakness. Pre-existing faults may have been reactivated. The two fault generations occur superimposed in the same zone and result in a tectonic graben with the same orientation as the intermediate zone. The graben probably evolved during several stages: initially tensional stresses occurred, and subsequently a transpressional regime developed probably, accompanied by strike-slip stresses parallel to the graben direction.

Glaciotectonic deformations in the intermediate zone die gradually out to a depth of approx. $300 \mathrm{~m}$. Glaciotectonic structures suggest a transpressional regime due to the relative movement of the ice lobes.

Both the top-Neogene and individual Pleistocene marker horizons occur commonly some $20 \mathrm{~m}$ lower in the western region than in the eastern one. This is probably due to smaller glacio-isostatic rebound in the western province after the retreat of the last ice sheet, because the area was more predisposed to subsidence. Another explanation could be a higher ice-induced compaction of sediments in the western 
region, where the sedimentary successions are much thicker.

The structural analysis proves the occurrence of intense tectonic movements induced by the Pleistocene ice sheets at the site of the (deep-seated) western slope of the East European craton. The Mazury and Warmia regions n NE Poland were previously considered to have been tectonically inactive since the Late Cretaceous.

\section{References}

Boulton, G.S. \& Dobbie, K.E. , 1993. Consolidation of sediments by glaciers: relation between sediment geotechnics, soft-bed glacier dynamics and subglacial ground-water flow. Journal of Glaciology 39, 26-44.

Dadlez, R. \& Jaroszewski, W., 1994. Tektonika. PWN.

Jarosiński, M., 1999. Badania współczesnych naprężeń skorupy ziemskiej w głębokich otworach wiertniczych w Polsce metodą analizy struktur breakouts. Instrukcje i metody badań geologicznych 56, 1-147.

Jaroszewski, W., 1991. Rozważania geologicznostrukturalne nad genezą zaburzeń glacitektonicznych (Considerations on the origin of glaciotectonic structures). Annales Societatis Geologorum Poloniae 61, 153-206.

Kenig, K., 1998. Petrogaficzne podstawy stratygrafii glin morenowych Polski północno-wschodniej (Petrographic foundations of till stratigraphy of northeastern Poland). Biuletyn Państwowego Instytutu Geol.ogicznego 380, 1-99.

Kotański, Z., 1977. Rozwój paleotektoniczny wyniesionej części starej platformy w Polsce w wałdaju i w kambrze (Palaeotectonic development of the uplifted part of the old (EastEuropean) platform in Poland, during the Valdaian and the Cambrian), Biuletyn Państwowego Instytutu Geol.ogicznego 303, 15 - 40.

Książkiewicz, M., Oberc, J. \& Pożaryski, W., 1974. Mapa tektoniczna Polski (Tectonic Map of Poland). Wydawnictwa Geologiczne.

Morawski,W., 2003. Reconstruction of ice-sheet movement from the orientation of linear glacial landforms and glaciotectonic deformations near Kronowo (western Mazury, Poland). Geological Quarterly 47, 339-356.

Morawski, W., 2004. Struktury glacitektoniczne południowej Warmii. (Glaciotectonic structures of the southern Warmia region - Poland), Prace Państwowego Instytutu Geologicznego 181, 109-142.

Morawski, W., 2005a. Warmińska prowincja paleogeograficzna plejstocenu (południowo-wschodnia Polska) (The Warmia Palaeographic Province of the Pleistocene - NE Poland), Przeglad Geologiczny 53, 477-488.

Morawski, W., 2005b. Reconstruction of ice sheet movement from the orientation of glacial morpholineaments (crevasse landforms): an example from northeastern Poland. Geological Quarterly 49, 403-416.
Morawski, W., 2009a. Szczegółowa mapa geologiczna Polski w skali 1:50 000 ark. Biskupiec (Detailed Geological Map of Poland, 1:50,000, sheet Biskupiec). Polish Geological Institute.

Morawski, W., 2009b. Szczegółowa mapa geologiczna Polski w skali 1:50 000 ark. Dźwierzuty (Detailed Geological Map of Poland, 1:50,000, sheet Dźwierzuty). Polish Geological Institute.

Morawski, W., 2009c. Objaśnienia do szczegółowej mapy geologicznej Polski w skali 1:50 000 ark. Dźwierzuty (Explanations to Detailed Geological Map of Poland, 1:50,000, sheet Dźwierzuty). Polish Geological Institute.

Morawski, W., 2009d. Differences in the regional stratigraphy of NE Poland caused by vertical movements due to glacioisostasy. Geologos 15, 235250 (this issue).

Morawski W., Jóźwiak, W., Krzywiec, P., Marks, L., Petecki, Z. \& Twarogowski, J., 2004. Kompleksowe zastosowanie metod geofizycznych do badań osadów kenozoicznych na przykładzie południowej Warmii (Integrated geophysical study of the Cenozoic complex as exemplified from southern Warmia region - Poland). Prace Państwego Instytutu Geologicznego 181, 143-164.

Piwocki, M., 2004. Paleogen i neogen południowej Warmii (Paleogene and Neogene of southern Warmia region - Poland). Prace Państwowego Instytutu Geologicznego $181,73-80$.

Rotnicki, K., 1976. The theoretical basis for and a model of the origin of glaciotectonic deformations. Quaestiones Geographicae 3, 103-139.

Słodkowska, B., 2009. Palynology of the Palaeogene and Neogene from the Warmia and Mazury areas (NE Poland). Geologos, 15, 219-234 (this issue).

Tyski, S. [Ed.], 1969. Synekliza perybałtycka. 1. Budowa geologiczna. Prace geostrukturalne Instytutu Geologicznego. Warszawa

Tyski, S., 1974. Obszar wyniesiony platformy wschodnio europejskiej. [In:] W. Pożarski (Ed.) - Budowa geologiczna Polski Tektonika, cz. 1. Niż Polski. Wydawnictwa Geologiczne.

Wiejacz, P., 2004. Preliminary investigation of the September 21 2004, earthquakes of Kaliningrad region, Russia. Acta Geophysica Polonica 52, 425-441.

Wyrzykowski, T., 1985. Mapa prędkości współczesnych pionowych ruchów skorupy ziemskiej na obszarze Polski. Instytut Geodezji i Kartografii. Warszawa.

Uścinowicz, S., 2003. Relative sea level changes, glacioisostatic rebound and shoreline displacement in the Southern Baltic. Polish Geological Institute Special Paper $10,1-80$.

Zuchiewicz, W., Badura, J. \& Jarosiński, M., 2007. Neotectonics of Poland: an overwiev of active faulting. Studia Quaternaria 24, 5-20.

Manuscript received 15 September 2008; revision accepted 17 November 2009. 